\title{
Penalaran Matematis Siswa SMK dalam Memecahkan Masalah Perbandingan Trigonometri
}

\author{
I'im Fatimah ${ }^{1}$, I Made Sulandra ${ }^{1}$, Gatot Muhsetyo ${ }^{1}$ \\ ${ }^{1}$ Pendidikan Matematika-Universitas Negeri Malang
}

\begin{tabular}{l}
\hline INFO ARTIKEL \\
\hline Riwayat Artikel: \\
Diterima: 04-03-2019 \\
Disetujui: 16-08-2019 \\
\hline
\end{tabular}

\section{Kata kunci:}

mathematical reasoning; solve the problem; trigonometric comparison; penalaran matematis; memecahkan masalah; perbandingan trigonometri

\begin{abstract}
ABSTRAK
Abstract: The reasoning abilities of Vocational students are still low. This qualitative study describes student's mathematical reasoning in solving problems based on Polya's steps. The subjects were three students, high (ST), medium (SS), and low (SR). Research was conducted by analyzing the work results subjects and interviews. Research shows that Understanding problems, subjects analysed problem:ST, SS, SR revealed problem information; ST was relevant in representing triangles, SS, SR; ST identified tangen, SS, SR sine rule. Planning, subjects connected the trigonometric comparison. Implementing plans, subjects applied strategies:ST used procedure by setting the solution step and the correct calculation, SS, SR incorrect; ST, SS reviewed strategies by checking the calculation/formulas, SR not. Looking back, subjects reflected the solution:ST, SS did not write the conclusion and considered the fairness of the solution, SR not.

Abstrak: Kemampuan penalaran siswa SMK masih rendah. Penelitian kualitatif ini mendeskripsikan penalaran matematis siswa dalam memecahkan masalah, berdasarkan langkah Polya.Subjek penelitian tiga siswa yaitu berkemampuan tinggi (ST), sedang (SS), dan rendah (SR). Penelitian dilakukan dengan menganalisis hasil pekerjaan siswa dan wawancara. Penelitian menunjukkan bahwa saat memahami masalah, ketiga subjek menganalisis masalah ST, SS, SR mengungkapkan informasi masalah; ST relevan dalam merepresentasikan segitiga, SS, SR tidak; ST mengidentifikasi konsep trigonometri tangen, SS, SR aturan sinus. Ketika merencanakan,ketiga subjek mengoneksikan perbandingan trigonometri.Ketika melaksanakan rencana, ketiga subjek menerapkan strategi: ST menggunakan prosedur dengan mengatur langkah solusi terarah dan perhitungan tepat, SS, SR tidak tepat; ST, SS meninjau strategi dengan mengecek perhitungan/rumus,SR tidak.Ketika memeriksa kembali, ketiga subjek merefleksikan solusi: ST, SS tidak menuliskan kesimpulan; ST, SS mempertimbangkan kewajaran solusi, SR tidak.
\end{abstract}

\section{Alamat Korespondensi:}

I'im Fatimah

Pendidikan Matematika

Universitas Negeri Malang

Jalan Semarang 5 Malang

E-mail: fatimah140485@gmail.com

Pembelajaran matematika penting dalam mempersiapkan siswa SMK menghadapi abad 21. Hal ini sesuai dengan Partnership for $21^{\text {st }}$ Century Learning (2016), menyatakan bahwa agar siswa berhasil "di dunia di mana perubahan terjadi konstan dan belajar tidak pernah berhenti”, maka penguasaan mata pelajaran akademik yang mendasar seperti matematika diidentifikasi penting untuk keberhasilan siswa. Pembelajaran matematika di sekolah berpedoman pada kurikulum, yaitu kurikulum 2013. Pada kurikulum 2013, standar kompetensi lulusan mencakup pengembangan ranah sikap, pengetahuan dan keterampilan. Dari ketiga ranah tersebut, ranah keterampilan yang dicapai siswa adalah kemampuan siswa untuk mengolah, menalar dan menyaji dalam ranah konkret dan ranah abstrak terkait dengan pengembangan dari yang dipelajariya di sekolah secara mandiri, dan mampu menggunakan metode sesuai kaidah keilmuan. Hal ini dapat dipahami bahwa salah satu keterampilan yang harus dikuasai siswa adalah menalar, akibatnya dalam pembelajaran matematika siswa diharapkan memiliki kemampuan penalaran.

Penalaran merupakan cara atau proses seseorang dalam berpikir untuk mendapatkan kesimpulan (pengetahuan) yang logis berdasarkan fakta empiris yang dapat diobservasi dan sumber yang relevan. Hal ini sesuai dengan pendapat (Suriasumantri, 2001). Keterampilan penalaran, pemecahan masalah, komunikasi, membuat koneksi dan menggunakan representasi merupakan keterampilan yang membentuk dasar pemikiran matematika. Hubungannya dengan berpikir matematis (Stacey, 2006) menyatakan bahwa penalaran matematis merupakan bagian dari berpikir matematis, dimana berpikir matematis merupakan tujuan penting dari sekolah, berpikir matematis merupakan suatu cara penting dalam belajar matematika dan mengajar matematika. Mampu menggunakan pemikiran matematis dalam memecahkan masalah matematika merupakan salah satu tujuan paling mendasar dalam pembelajaran matematika. Sejalan dengan itu, penalaran merupakan tujuan utama dari semua instruksi, guru matematika 
mempunyai kesempatan untuk menolong siswa mengembangkan kemampuan penalarannya (Krulik, Rudnick, \& Milou, 2003) sehingga penalaran matematis bagian dari pemikiran matematis yang menjadi tujuan penting dalam pembelajaran matematika

Pemecahan masalah penting dalam pembelajaran matematika dan sebagai cara untuk membiasakan siswa bernalar matematis. Sesuai dengan pendapat (Krulik et al., 2003) yang menyatakan bahwa mengajarkan pemecahan masalah sangat penting, karena menyelesaikan masalah adalah kejadian sehari-hari yang harus dihadapi semua siswa dan sebagai cara mengajar siswa untuk berpikir atau bernalar melalui proses pemecahan masalah. (Lithner, 2008) mendefinisikan penalaran sebagai cara untuk memahami mekanisme di balik strategi-strategi yang berkaitan dengan penyelesaian permasalahan matematis. Penalaran matematis perlu dibiasakan dalam pembelajaran melalui aktivitas: menganalisis masalah, menerapkan strategi, menggunakan koneksi dan merefleksikan solusi (NCTM, 2010) Hal ini sesuai dengan pendapat (Safrida, As'ari, \& Sisworo, 2016) menyatakan bahwa kebiasaan bernalar yang dilakukan secara rutin dan terus menerus dapat meningkatkan kemampuan penalaran matematis siswa. (Mueller, Yankelewitz, \& Maher, 2014) menambahkan bahwa penalaran tidak hanya penting untuk mendapatkan pengetahuan baru dalam matematika, tetapi juga dapat mengaitkan pengetahuan matematika dengan bidang lainnya. Oleh karena itu, penalaran merupakan hal penting untuk dilakukan oleh siswa karena dapat membantu mereka dalam mempelajari bidang lainnya, misalnya ilmu teknik yang sedang digeluti siswa SMK.

Terkait dengan penalaran sebagai salah satu tujuan pembelajaran matematika, terdapat fakta bahwa penalaran matematis siswa kurang maksimal. Hal ini terlihat dari hasil observasi yang dilakukan oleh peneliti di SMK Negeri 3 Tuban tepatnya di kelas XI pada Kamis, 30 September 2017. Berdasarkan hasil observasi dapat diketahui bahwa persentase kesalahan konstruksi terbesar siswa SMK dalam memecahkan masalah matematika adalah kesalahan dalam bernalar yaitu sebesar 87\%, Hal ini sesuai dengan pendapat (Mueller et al., 2014) yang menyatakan bahwa banyak siswa mengalami kesulitan dalam bernalar .

Pada kesempatan yang berbeda, peneliti juga mengobservasi kemampuan pemecahan masalah siswa SMK, siswa diberikan soal sederhana tentang trigonometri sebagai berikut. "Diketahui $\triangle D E F$ dengan $D F=F E, \angle D F E=90^{\circ}$ dan panjang DE adalah $10 \mathrm{~cm}$, tentukan panjang DF !". Salah satu contoh jawaban siswa dapat dilihat pada gambar 1.

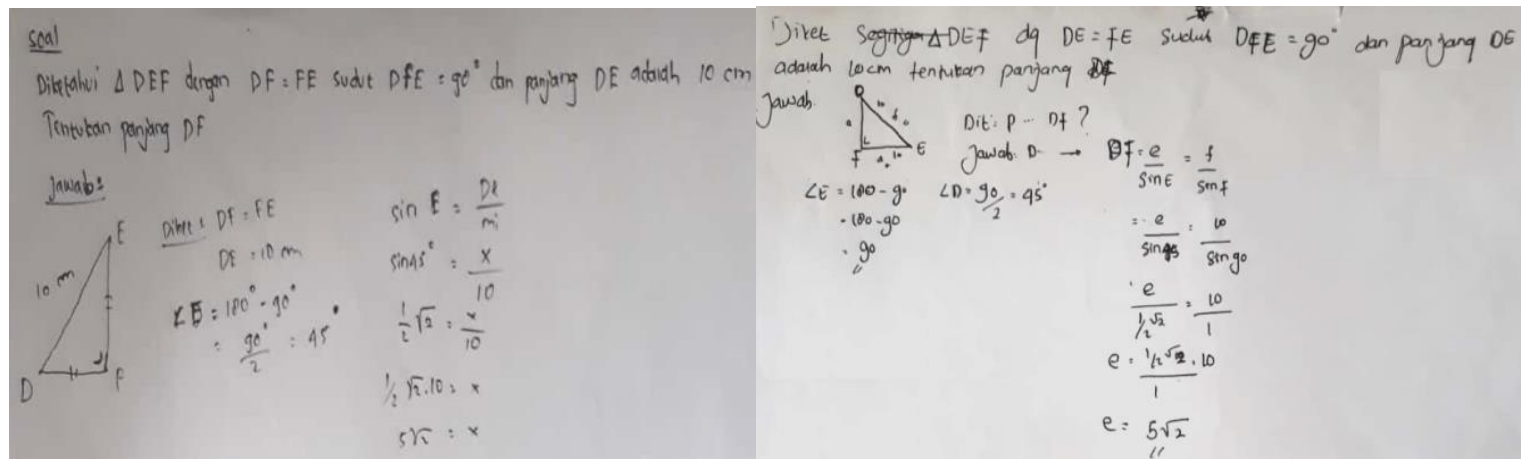

Gambar 1. Jawaban Siswa Benar dalam Menyelesaikan Soal

Berdasarkan hasil observasi pada kelas XII tersebut, 6,25\% siswa dari 32 siswa menjawab benar, sedangkan 93,75\% siswa menjawab salah. Dari 93,75\% siswa yang menjawab salah tersebut, ternyata siswa tidak memahami maksud soal (konsep segitiga) dengan baik yang mengindikasikan bahwa penalaran siswa SMK kurang maksimal. Pernyataan tersebut sesuai dengan pendapat Wahyudin (Nurhajati, 2014) menyatakan bahwa salah satu penyebab siswa gagal memahami pokok-pokok bahasan dalam matematika karena kurangnya penggunaan nalar dalam menyelesaikan permasalahan yang diberikan.

Pada kurikulum 2013, trigonometri merupakan salah satu materi yang dipelajari dalam matematika sekolah jenjang SMA/SMK, selain sebagai salah satu materi ujian nasional, trigonometri juga merupakan pelajaran matematika yang penting karena dapat meningkatkan berbagai keterampilan kognitif siswa dan memiliki area penggunaan yang luas dalam kehidupan sehari-hari (Tuna, 2013). Trigonometri memiliki area aplikasi yang cukup besar dalam bidang astronomi dan geografi, dan juga bidang geometri, fisika, optik, listrik, kartografi, dan maritime (Saglam et al., 2007). Trigonometri juga merupakan transisi dari aljabar ke geometri. Selain itu, fungsi dan sifat trigonometri digunakan dalam banyak materi termasuk limit, turunan, integral, dll.

(Tuna, 2013), menyatakan bahwa Trigonometri adalah konsep penting yang dapat meningkatkan keterampilan penalaran siswa. Menurut studi yang dilakukan oleh (Tatar, Okur, \& Tuna, 2008), Trigonometri adalah salah satu materi yang paling banyak siswa mengalami kesulitan dalam memahami. Hal ini sesuai dengan pendapat (Durmuş, 2004) menyatakan bahwa Trigonometri adalah salah satu materi dimana siswa mengalami kesulitan pembelajaran. Ketidakpahaman konsep segitiga yang merupakan konsep dasar trigonometri adalah salah satu alasan penting yang menyebabkan siswa mengalami kesulitan belajar pada materi trigonometri (Steckroth, 2007).

Berdasarkan uraian mengenai pentingnya penalaran matematis, hasil observasi awal, dan pendapat bahwa trigonometri dapat meningkatkan keterampilan penalaran, maka penting untuk melakukan penelitian terkait tentang penalaran matematis siswa dalam memecahkan masalah perbandingan trigonometri. Oleh karena itu, peneliti akan melakukan penelitian dengan judul "Penalaran Matematis Siswa SMK dalam Memecahkan Masalah Perbandingan Trigonometri”. 


\section{METODE}

Jenis penelitian ini adalah penelitian kualitatif yang dilaksanakan di SMK Negeri 3 Tuban dengan prosedur yaitu mengikuti tahap-tahap (a) merumuskan indikator penalaran dalam pemecahan masalah matematika berdasarkan teori dan penelitian yang relevan, (b) merumuskan instrument pendukung (tugas pemecahan masalah matematika dan pedoman wawancara) yang valid dan reliabel, (c) menentukan subjek penelitian dengan memberikan tes kemampuan matematika (d) melakukan pengambilan data untuk mengungkap penalaran matematis siswa dalam pemecahan masalah matematika, (e) melakukan triangulasi data untuk mendapatkan data yang valid, (f) melakukan analisis data penalaran matematis dalam pemecahan masalah ditinjau dari kemampuan matematika, (g) melakukan pembahasan hasil analisis, (h) melakukan penarikan kesimpulan hasil penelitian.

Instrumen-instrumen dalam penelitian ini adalah (1) tes kemampuan matematika, (2) lembar tes pemecahan masalah (ltpm), (3) pedoman wawancara. Untuk mengumpulkan data dalam penelitian ini dilakukan dengan cara subjek diberi kertas untuk mengerjakan tes pemecahan masalah, kemudian subjek diminta menceritakan secara rinci aktivitas mentalnya dalam memecahkan masalah perbandingan trigonometri. Selanjutnya, dilakukan wawancara. Keabsahan data penting dalam penelitian kualitatif. Pemeriksaan terhadap keabsahan data bertujuan untuk mengurangi bias yang terjadi pada saat pengumpulan data.

Tiga siswa kelas XII SMK Negeri 3 Tuban dijadikan subjek penelitian, yang terdiri dari subjek berkemampuan tinggi (ST), subjek berkemampuan sedang (SS), dan subjek berkemampuan rendah (SR). Masalah matematika perbandingan trigonometri yang dikerjakan siswa dapat dilihat pada gambar 2.

Rino diminta mengukur tinggi tiang bendera.

Pertama, untuk mengetahui jarak ia berdiri terhadap tiang bendera, Rino mengikatkan tali pada tiang bendera kemudian ditarik (tegak lurus dengan tiang bendera) hingga batas ia berdiri dan hasil pengukuran panjang tali tersebut adalah $50 \mathrm{~m}$. Selanjutnya, Saat posisi berdiri, Rino memeriksa ujung tiang bendera menggunakan klinometer untuk mengetahui sudut yang dibentuk. Jika sudut yang dibentuk adalah $60^{\circ}$ dan tinggi badan Rino dari mata hingga telapak kaki adalah $170 \mathrm{~cm}$. Berapakah tinggi tiang bendera tersebut?

\section{Gambar 2. Soal Tes Pemecahan Masalah}

\section{HASIL}

Penalaran Matematis ST dalam Memecahkan Masalah

Paparan data hasil tes tulis ST dalam memecahkan masalah disajikan pada gambar 3.
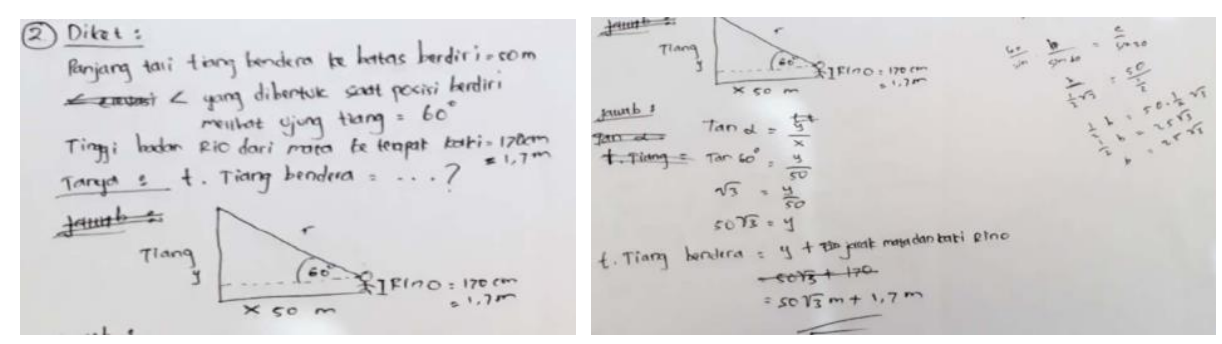

\section{Gambar 3. Lembar Jawaban ST dalam menyelesaikan tes pemecahan masalah}

Berdasarkan Jawaban ST gambar 3, ST memahami masalah dengan melakukan aktivitas penalaran matematis menganalisis masalah, yaitu:

1. ST mengungkapkan informasi penting tentang masalah dengan baik, yang ditunjukkan dengan menuliskan informasi-informasi yang diketahui dan informasi yang ditanyakan, seperti yang disajikan pada gambar 4 dan petikan wawancara (PT206), (ST206), (PT207), (ST207).

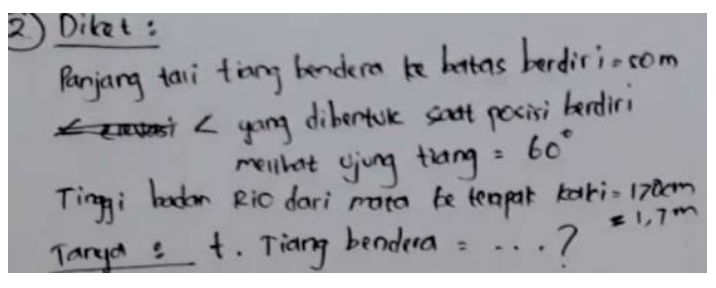

ST mengungkapkan informasi penting tentang masalah

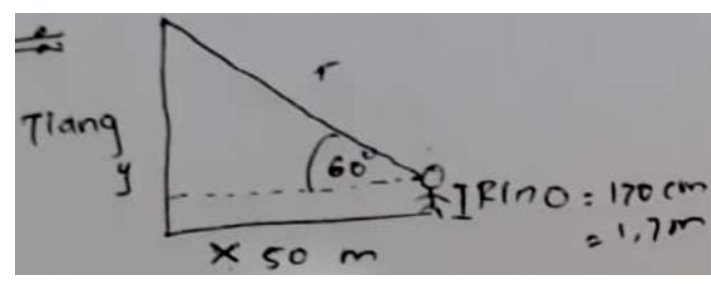

ST merepresentasikan segitiga siku-siku yang relevan 


\section{Gambar 4. ST mengungkapkan informasi tentang masalah dan merepresentasikan segitiga siku-siku yang relevan}

PT206: Informasi apa saja yang kamu ketahui pada soal ini?.

ST206 : Panjang tali tiang bendera ke batas berdiri 50m, sudut yang dibentuk saat posisi berdiri memeriksa ujung tiang $60^{\circ}$, tinggi badan Rino dari mata hingga kaki $170 \mathrm{~cm}$.

PT207: Apa yang ditanyakan pada soal tersebut?.

ST207: Tinggi tiang bendera?.

2. ST merepresentasikan segitiga siku-siku yang relevan dengan benar untuk mengungkapkan informasi penting tentang masalah, seperti yang disajikan gambar 4. Hal ini perlu dilakukan ST agar lebih mudah untuk menemukan cara dalam menjawab pertanyaan (PT204), (ST204)

PT204: Kenapa perlu?.

ST204 : Karena disoal ini hanya disebutkan ukuran2nya saja dan belum signifikan sehingga perlu digambarkan maksud soal tersebut, selain itu untuk mempermudah saya menemukan cara/langkah-langkah penyelesaian.

3. ST mengidentifikasi konsep trigonometri tangen, meskipun awalnya menggunakan konsep trigonometri aturan sinus, seperti yang disajikan gambar 5 dan petikan wawancara (ST215), namun karena perhitungannya cukup panjang, akhirnya mencoba mencari cara lain yaitu perbandingan trigonometri tangen (PT216), (ST216).
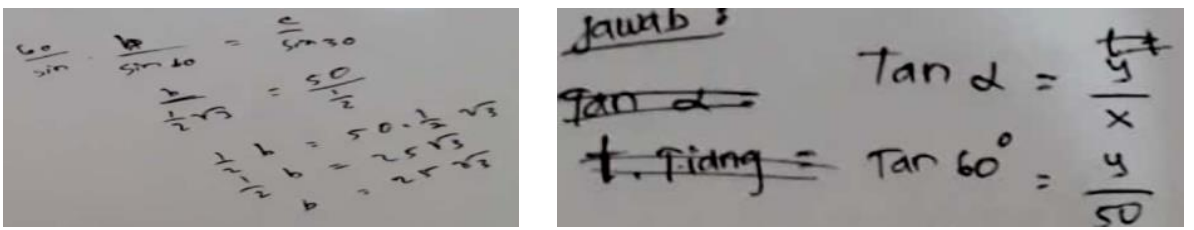

\section{Gambar 5. ST mengidentifikasi konsep trigonometri}

PT215 : Mengapa pada lembar jawaban mu, ada perhitungan menggunakan rumus aturan sinus?.

ST215 : Oiya bu, sebelum saya menggunakan rumus tangen, saya sempat mencoba dengan rumus aturan sinus bu, namun ternyata kurang tepat dalam soal ini.

PT216: Kurang tepatnya dimana?.

ST216: Saya tidak tahu bu, saya hanya coba-coba..secara refleks saya mencoba dengan menggunakan rumus aturan sinus, kemudian perhitungannya kok cukup panjang, akhirnya saya memeriksa kembali gambar yang saya buat, kemudian mencoba mencari cara lain dengan menggunakan rumus tangen.

Selanjutnya, Setelah memahami masalah, ST membuat rencana penyelesaian masalah dengan melakukan aktivitas penalaran menggunakan koneksi yaitu ST mengoneksikan masalah yang dipahami dengan materi perbandingan trigonometri tangen, sesuai petikan wawancara (PT211) dan (ST211).

PT211: Kira-kira rencana kamu akan menggunakan materi apa saja untuk menyelesaikan soal ini?.

ST211 : Materi yang saya gunakan dengan rumus trigonometri, lebih tepatnya rumus tangen.

Berdasarkan jawaban ST gambar 3 setelah ST membuat rencana, ST melaksanakan rencana penyelesaian masalah dengan melakukan aktivitas penalaran menerapkan strategi penyelesaian masalah.

1. ST menggunakan prosedur penyelesaian secara terarah dengan mengatur langkah-langkah solusi, seperti yang disajikan Gambar 6 dan petikan wawancara (PT214), (ST214). Langkah solusi ST diantaranya menentukan panjang y (tinggi tiang bendera sampai batas mata Rino), kemudian mencari tinggi tiang bendera seluruhnya dengan menambahkan y dengan tinggi badan Rino dari mata hingga kaki (ST214). 


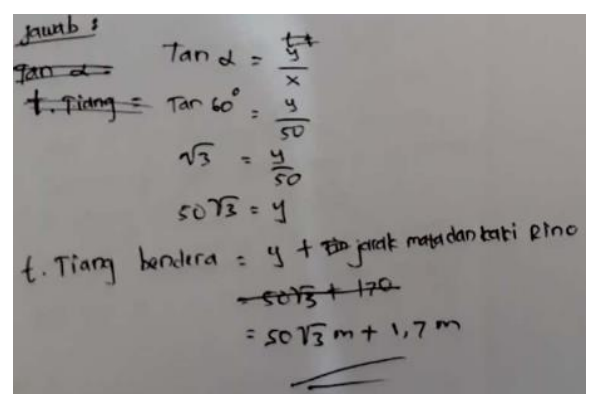

\section{Gambar 6. Prosedur penyelesaian secara terarah}

PT214 : Bagaimana langkah-langkah kamu selanjutnya dalam menyelesaikan soal ini?.

ST214: Setelah saya gambar, saya jawab saja bu, saya jawab dengan mengunakan sudut yang diketahui yaitu $60^{\circ}$, kemudian sudut $60^{\circ}$ tersebut menjadi acuan untuk mencari tinggi tiang bendera, tapi tinggi tiang bendera tersebut belum tinggi keseluruhan bu, nanti tinggi tiang benderanya akan saya jumlahkan dengan tinggi Rino dari mata hingga kaki untuk mendapatkan tinggi tiang bendera seluruhnya.

Pertama saya pakai tan $60^{\circ}$ sama dengan sisi depan per sisi samping, sisi depan sudut adalah tinggi tiang bendera sampai batas mata Rino, saya umpamakan y kemudian dibagi jarak Rino ke tiang bendera 50m, sehinnga tinggi tiang bendera sampai batas mata Rino adalah $50 \sqrt{3}$. Kemudian untuk mendapatkan tinggi tiang bendera seluruhnya adalah menambahkan y dengan tinggi badan Rino dari mata hingga kaki.

2. ST melakukan peninjauan strategi yang dipilih dengan melakukan pengecekan perhitungan ataupun rumus, Seperti yang disajikan gambar 7 dan petikan wawancara (PT219), (ST219). ST sempat melakukan kesalahan penulisan rumus maupun penulisan bilangan yang satuannya belum sama, sesuai petikan wawancara (PT221), (ST221), (PT223), (ST223).

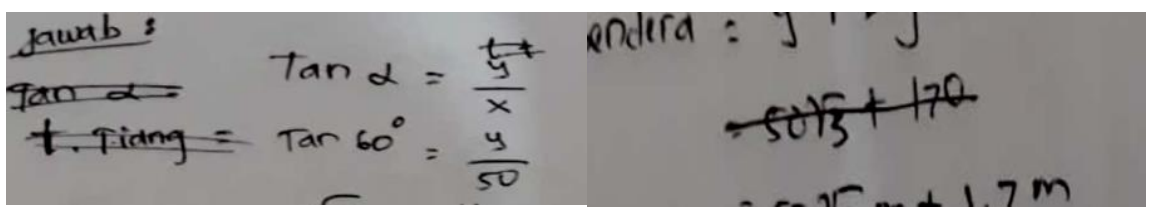

Gambar 7. ST melakukan pengecekkan rumus ataupun perhitungan

PT219: Apakah kamu mengecek kembali setiap langkah-langkah tersebut untuk memastikan arahan dalam menjawab solusi?.

ST219: Sudah saya cek.

PT221: Coba jelaskan, kenapa langkahmu itu salah?.

ST221: Kesalahan yang saya buat ini kesalahan tulis saja..tidak ada kesalahan rumus.

PT223 : Selain kesalahan tulis,adakah kesalahan lainnya yang kamu lakukan?.

ST223: Ada bu, kesalahan saya ketika ada bilangan dalam satuan m saya jumlahkan dg satuan cm, kemudian saya ganti.

Berdasarkan jawaban ST gambar 3, setelah ST melaksanakan rencana, ST memeriksa kembali selesaian yang diperoleh dengan melakukan aktivitas penalaran merefleksikan solusi yaitu ST menafsirkan solusi untuk menjawab masalah secara implicit dengan memberi dua garis dibawah pada solusi yang diperoleh gambar 8 dan dapat menyimpulkan solusi untuk menjawab masalah (PT225), (ST225), namun ST tidak menuliskan kesimpulan tersebut karena lupa (PT226), (ST226). Selain itu, ST juga yakin dengan jawaban yang ditemukan (PT227), (ST227) karena ST merasa sudah menggunakan rumus dan perhitungan yang benar (PT228), (ST228).

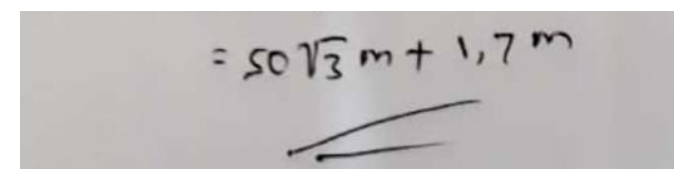

\section{Gambar 8. ST menafsirkan solusi secara implicit}

PT225: Kesimpulanmu apa dalam menjawab soal ini?.

ST225 : Jadi tinggi tiang bendera adalah 50akar 3 ditambah 1,7 meter.

PT226: Kenapa tidak kamu tuliskan kesimpulanmu ini pada lembar jawabanmu?.

ST226: Maaf bu lupa, karena terburu-buru takut waktunya habis karena belum ngerjkan soal yang lain, soal no 1 dan no.3. 
PT227: Apakah kamu sudah yakin dengan jawabanmu?.

ST227: Sudah bu.

PT228: Bagaimana cara kamu untuk menunjukkan jawabanmu itu benar?.

ST228: Karena saya menggunakan rumus yang benar, yaitu menggunakan rumus tangen sesuai dengan masalah tersebut dan perhitungan saya sudah benar.

\section{Penalaran Matematis SS dalam Memecahkan Masalah}
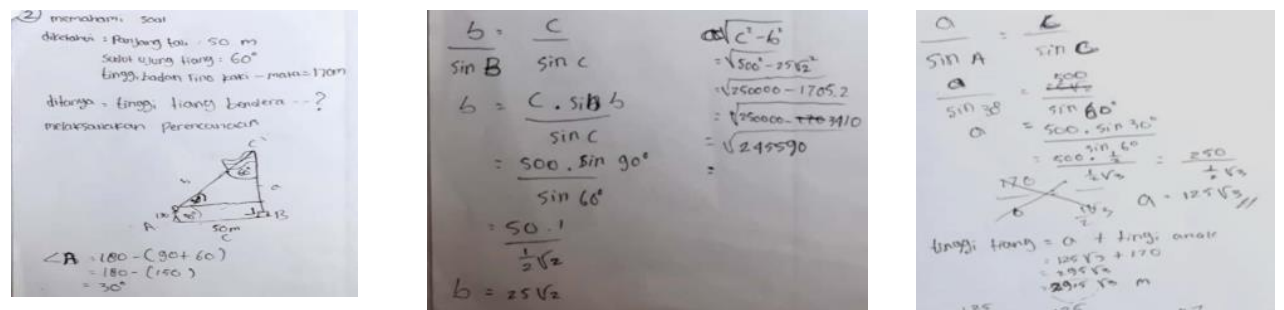

Gambar 9. Lembar Jawaban SS dalam menyelesaikan tes pemecahan masalah nomor 2

Berdasarkan Jawaban SS gambar 9 SS memahami masalah dengan melakukan aktivitas penalaran matematis menganalisis masalah, yaitu:

1. SS mengungkapkan informasi penting tentang masalah dengan baik, yang ditunjukkan dengan menuliskan informasi-informasi yang diketahui dan informasi yang ditanyakan, seperti yang disajikan pada gambar 10 dan petikan wawancara (PS203), (SS203), (PS204), (SS204), (PS205), (SS205), (PS209), (SS209).

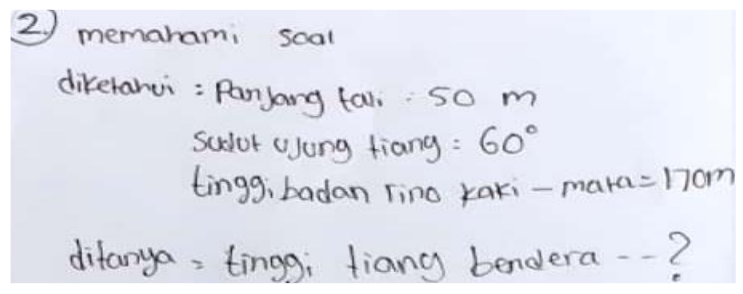

Gambar 10. SS mengungkapkan informasi penting tentang masalah

PS203: Apa yang diketahui di soal?.

SS203: Panjang tali bendera $50 \mathrm{~m}$.

PS204 : Panjang tali bendera, Maksudnya apa itu?.

SS204: Jarak antara tiang bendera dengan Rino.

PS205: Selanjutnya?.

SS205: Sudut yang dibentuk 60 derajat dan tinggi badan rino $170 \mathrm{~cm}$.

PS209: Yang ditanyakan pada soal tersebut apa?.

SS209: Tinggi tiang bendera.

2. SS merepresentasikan segitiga siku-siku dalam mengungkapkan informasi penting tentang masalah, namun kurang relevan dan kurang tepat, seperti yang disajikan gambar 11. SS merasa perlu merepresentasikan segitiga siku-siku, dikarenakan agar lebih mudah dalam menyelesaikan soal, sesuai petikan wawancara (PS206), (SS206), (PS207),(SS207). SS juga merasa yakin bahwa representasi segitiga siku-siku yang dibuat benar (SS216), namun SS tidak mengetahui klinometer (PS217), (SS217). Selanjutnya, SS merepresentasikan peletakkan sudut $60^{\circ} \mathrm{kurang}$ tepat, karena SS memahami bahwa "Rino memeriksa ujung tiang bendera", berarti sudutnya berada di ujung tiang bendera, sesuai petikan wawancara (PS218), (SS218). 


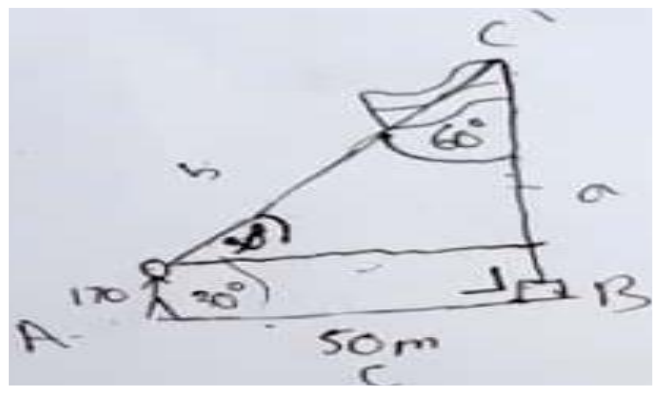

\section{Gambar 11. SS merepresentasikan segitiga siku-siku yang kurang relevan}

PS206 : Apakah kamu perlu menggambarkan maksud soal tersebut?.

SS206: Perlu bu.

PS207: Kenapa perlu?

SS207: Agar mengetahui dimana nilai-nilainya, atau sisi-sisinya dan untuk mempermudah pekerjaan.

PS216: Apa kamu yakin dengan gambar mu ini?.

SS216: Yakin.

PS217: Apa kamu tahu klinometer?.

SS217: Tidak bu, bentuknya aja ga tahu.

PS218: Kenapa sudut 60, kamu letakkan disini (sambil menunjuk gambar)?.

SS218: Karena di soal kan Rino memeriksa ujung tiang bendera menggunakan klinometer untuk mengetahui sudut yang dibentuk. jadi kan sudutnya berada di ujung tiang bu.

3. SS mengidentifikasi konsep trigonometri dengan menggunakan aturan sinus, seperti yang disajikan Gambar 12 dan petikan wawancara (SS223)

4.

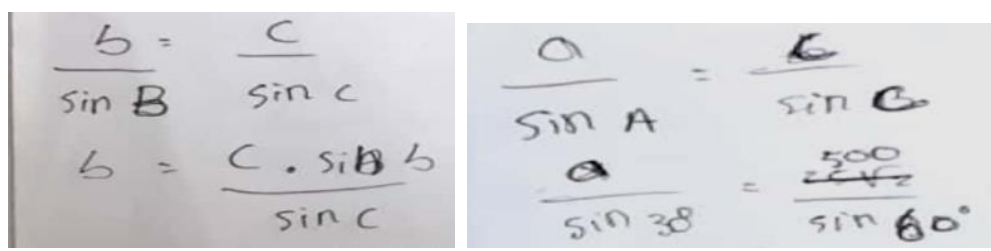

Gambar 12. SS meengidentifikasi konsep trigonometri

PS223: Ok, mencari b pake apa?.

SS223: Perbandingan trigonometri aturan sinus.

$\mathrm{b}$ per $\sin \mathrm{B}=\mathrm{c}$ per $\sin \mathrm{C}$ (dibaca setiap langkah yang ditulis), Sehingga ketemu $\mathrm{b}=25$ akar 2.

Selanjutnya, Setelah memahami masalah, SS membuat rencana penyelesaian masalah dengan melakukan aktivitas penalaran menggunakan koneksi yaitu SS mengoneksikan masalah yang dipahami dengan materi perbandingan trigonometri (atuan sinus) dan pythagoras, sesuai petikan wawancara (PS212) dan (SS212).

PS212: Kira-kira rencana kamu akan menggunakan materi apa saja untuk menyelesaikan soal ini?.

SS212: Trigonometri, Pythagoras.

Berdasarkan jawaban SS (gambar 9), Setelah SS membuat rencana, SS melaksanakan rencana penyelesaian masalah dengan melakukan aktivitas penalaran menerapkan strategi penyelesaian masalah, yaitu:

1. SS menggunakan prosedur penyelesaian dengan mengatur langkah-langkah solusi cukup terarah, namun beberapa perhitungan kurang tepat, seperti yang disajikan gambar 13. Langkah solusi SS yaitu menentukan sudut A (SS215); kemudian mencari panjang a (tinggi tiang bendera sampai batas mata Rino) awalnya dengan teorema Pythagoras (SS227), (PS222),(SS222), yang sebelumnya menentukan panjang b terlebih dulu (PS220), (SS220), (PS222), (SS222), (PS223), (SS223) namun karena SS merasa perhitungaan panjang b nya salah (PS231), (SS231), (PS232), (SS232) dan SS merasa panjang a perhitungannya sulit (SS229), akhirnya menggunakan cara berbeda untuk menemukan panjang a (PS230), (SS230), (PS236), (SS236); kemudian mencari tinggi tiang bendera seluruhnya dengan menambahkan a dengan tinggi badan Rino dari mata hingga kaki (SS244). Adapun prosedur penyelesaian SS cukup terarah namun kurang tepat dalam proses perhitungannya, diantaranya salah dalam menentukan nilai trigonometri dari suatu sudut (PS224), (SS224); salah dalam mengkonversi satuan $\mathrm{cm} \mathrm{ke} \mathrm{m} \mathrm{(PS238),} \mathrm{(SS238),}$ 
(PS239), (SS239); salah dalam melakukan perhitungan pembagian dan atau merasioalkan bentuk akar (PS242), (SS242), (PS243), (SS243); salah menggunakan rumus Pythagoras dalam menemukan panjang a (SS227); salah dalam menjumlahkan bilangan bentuk akar (SS244).

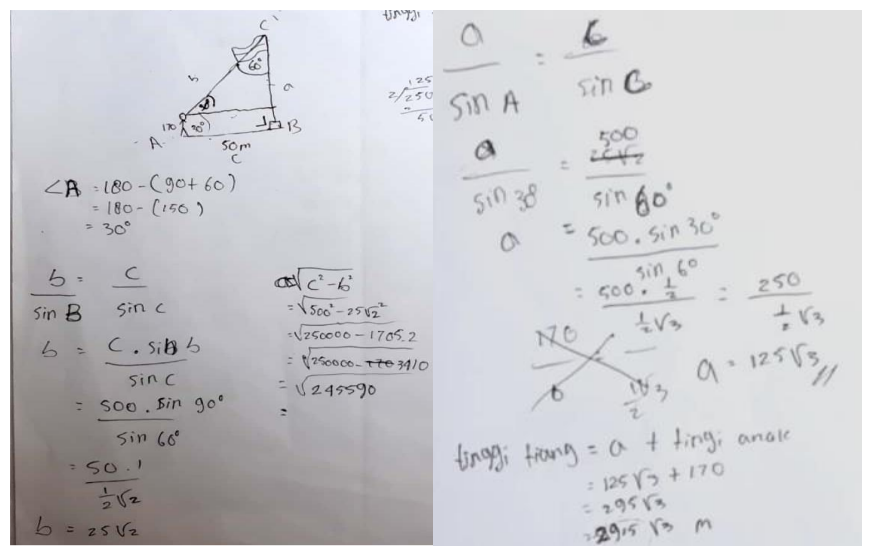

\section{Gambar 13. SS menggunakan prosedur penyelesaian secara terarah}

PS215: Langkah selanjutnya?.

SS215: Setelah menggambar, trus mencari sudut A Mencari sudut a dengan 180 dikurangi $(90+60)$ yang hasilnya 30 derajat.

PS220: Trus langkah selanjutnya?.

SS220 : Mencari panjang $b$ menggunakan rumus $b$ per $\sin b=c$ per $\sin c$.

PS222: Trus dalam gambarmu tinggi tiang bendera itu simbolnya apa?.

SS222: A bu, tapi nyari b dulu bu.

PS223: Ok, mencari b pake apa?.

SS223: Perbandingan trigonometri, aturan sinus.

$\mathrm{b}$ per $\sin \mathrm{B}=\mathrm{c}$ per $\sin \mathrm{C}$ (membaca setiap langkah yang ditulis), Sehingga ketemu $\mathrm{b}=25$ akar 2.

PS224: Sek, apa kamu yakin $\sin 60=1 / 2$ akar 2 ?.

SS224: Sambil berpikir kembali, ooiya bu sin 60 salah yang benar setengah akar 3 .

SS227: Saya mencari a dengan Pythagoras, $a=$ akar dari (c kuadrat dikurangi b kuadrat), (sambil mebacakan setiap angka pada langkah selanjutnya).

PS228: Dan ketemu?.

SS228: Itu belum ketemu bu a nya.

PS229: Terus, selanjutnya?.

SS229: Karena perhitungannya sulit,saya tidak melanjutkannya dan mencoba mencari cara lain .

PS230 : Cara lainnya apa?.

SS230 : Pake rumus a per $\sin \mathrm{A}=\mathrm{c}$ per $\sin \mathrm{C}$.

subjek membaca setiap langkah yang dikerjakan dan Guru mengamati langkah-langkah yang ditulis subjek.

PS231 : (setelah subjek membaca langkah pekerjaannya )Apakah kamu tidak melakukan pengecekkan?.

SS231: Saya sudah mengecek bu, kemudian saya sadar bahwa langkah sebelumnya salah, hasil yang saya temukan $b=25$ akar 3 salah.

PS232: Salahnya dimana?.

SS232: Nilai b nya 25 akar3, kok lebih kecil dari 50m. kan seharusnya lebih panjang.

PS236 : Selanjutnya coba jelaskn lagi cara yang kamu temukan?.

SS236 : Mencari nilai a dengan rumus a per $\sin \mathrm{a}=\mathrm{c}$ per sin c,Sehingga ketemu nilai $\mathrm{a}=125$ akar 3.

PS238: Oo gitu, trus 500 itu dari mana?

SS238: Dari $50 \mathrm{~m}$ saya rubah ke $\mathrm{cm}$. .jadi $500 \mathrm{~cm}$.

PS239: Apa kamu yakin konversimu meter ke cm benar?.

SS239: Yakin bu.

PS242: Kemudian 250 dibagi setengah akar 3 kok menjadi 125 akar 3, apa kamu yakin dengan perhitunganmu ini?.

SS242: Yakin bu.

PS243: Gimana cara menghitungmu?.

SS243: Dibagi 1 trus dibagi 2 bu, akar 3 nya tinggal mengikuti bu.

PS244: Oo gitu, langkah selanjutnya?.

SS244 : Kan langkah sebelumnya ketemu a= 125 akar 3, kemudian mencari tinggi tiang bendera dengan rumus a ditambah tinggi anak . jadi 125 akar 3 ditambah $170 \mathrm{~cm}$, jadi 295 akar $3 \mathrm{~cm}$ atau 29.5 akar $3 \mathrm{~m}$. 
2. SS melakukan peninjauan strategi yang dipilih dengan melakukan pengecekan perhitungan ataupun rumus. sesuai petikan wawancara (PS231), (SS231), (PS237), (SS237).

PS231: (Setelah subjek membaca langkah pekerjaannya)Apakah kamu tidak melakukan pengecekkan?.

SS231 : Saya sudah mengecek bu, kemudian saya sadar bahwa langkah sebelumnya salah, hasil yang saya temukan $b=25$ akar 3 salah.

PS237 : Sambil mengecek langkah pekerjaan subjek, 25 akar 2 kok dicoret diganti 500 knp?.

SS237: Awalnya saya pake rumus a per $\sin a=b$ per $\sin b$, Kemudian saat saya memasukkan nilai b, saya sadar bahwa hasil nilai $b$ yang saya peroleh tadi salah. Jadi rumus saya ganti dengan a per $\sin \mathrm{a}=\mathrm{c}$ per $\sin \mathrm{c}$.

Berdasarkan jawaban SS (gambar 9), setelah SS melaksanakan rencana, SS memeriksa kembali selesaian yang diperoleh dengan melakukan aktivitas penalaran merefleksikan solusi yaitu:

1. SS menafsirkan solusi untuk menjawab masalah secara lisan dan tidak menuliskannya pada lembar jawaban, karena tidak terbiasa melakukannya, sesuai petikan wawancara (PS245), (SS245), (PS246),(SS246).

PS245 : Apa kesimpulanmu dalam menjawab soal ini?.

SS245 : Tinggi tiang bendera adalah 29,5 akar $3 \mathrm{~m}$.

PS246: Kok tidak kamu tuliskan kesimpulan mu ini?.

SS246 : Karena tidak terbiasa bu, dengan menjawab seperti ini biasanya sudah cukup .

2. SS mempertimbangkan kewajaran solusi dengan mempertimbangkan hasil perhitungan tinggi tiang bendera yang diperoleh $29.5 \quad \sqrt{3}$ lebih pendek dibandingkan jarak Rino terhadap tiang bendera $50 \mathrm{~m}$, (SS248),(PS249),(SS249),(PS250),(SS250). Sehingga SS tidak yakin akan kebenaran jawabannya,(PS247), (SS247) berikut petikan wawancara SS.

PS247: Apa kamu yakin dengan hasil pekerjaan mu ini?.

SS247: Tidak yakin.

PS248: Kenapa tidak yakin?.

SS248: Proses perhitungan saya ini bu .

PS249: Perhitungan mana yg tidak yakin?.

SS249: Dari 500 ini sudah tidak yakin, hasilnya kok cuma segini, kok lebih pendek dari jarak Rino ke tiang bendera.kan seharusnya lebih tinggi.

PS250: Kenapa kok seharusnya lebih tinggi dari pada jarak Rino dengan tiang bendera?.

SS250 : Karena saya berpikir, tiang bendera disekolah kan lebih tinggi dibandingkan jarak yang mengukur.

\section{Penalaran Matematis SR dalam Memecahkan Masalah}

Paparan data hasil tes tulis ST dalam memecahkan masalah dapat dilihat pada gambar 14.

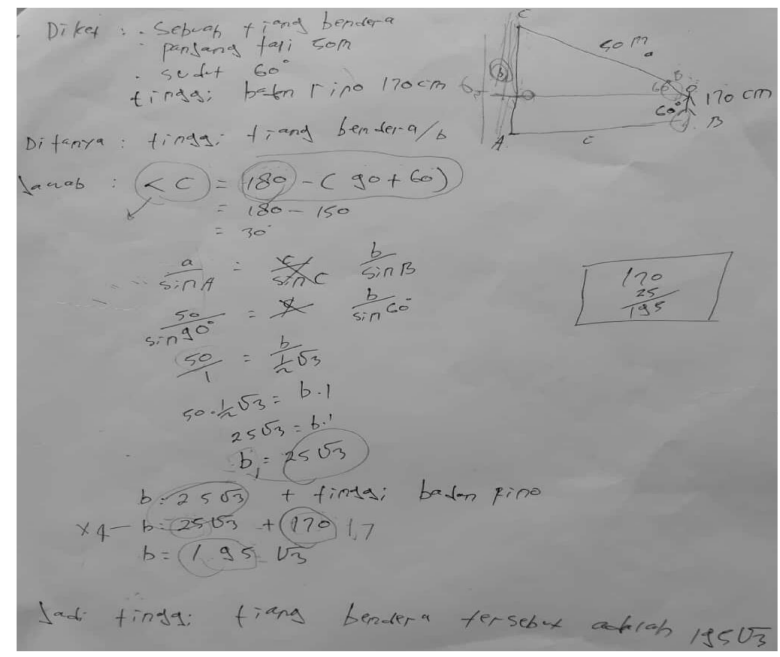

Gambar 14. Lembar Jawaban SR dalam menyelesaikan tes pemecahan masalah 
Berdasarkan jawaban SR gambar 14, SR memahami masalah dengan melakukan aktivitas penalaran menganalisis masalah, yaitu:

1. SR mengungkapkan informasi penting tentang masalah dengan baik, yang ditunjukkan dengan menuliskan informasi-informasi yang diketahui dan informasi yang ditanyakan, seperti yang disajikan gambar 15 dan petikan wawancara (PR208), (SR208), (PR209), (SR 209).

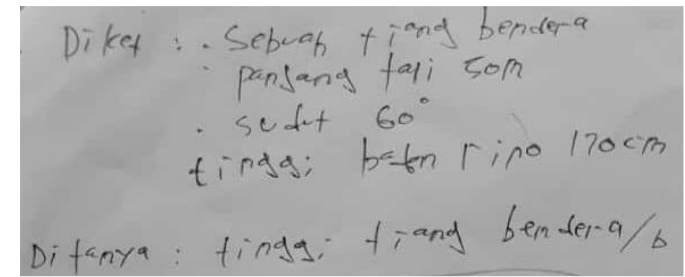

SR mengungkapkan informasi penting tentang masalah

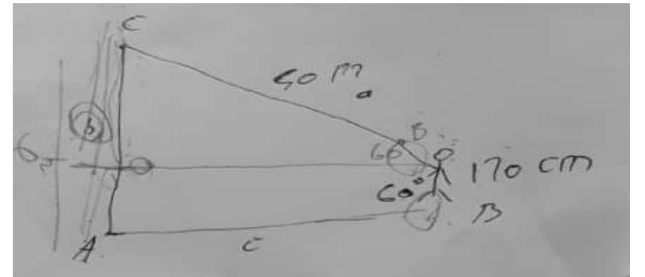

SR merepresentasikan segitiga siku-siku namun kurang relevan

\section{Gambar 15. SR mengungkapkan informasi penting tentang masalah dan merepresentasikan segitiga siku-siku}

PR208: Informasi apa saja yang kamu ketahui pada soal ini?.

SR208 : Panjang tali $50 \mathrm{~m}$, dengan sudut 60 derajat dan tinggi Rino dari kaki sampai mata $170 \mathrm{~cm}$.

PR209: Apa yang ditanyakan pada soal tersebut?.

SR209: Tinggi tiang bendera/ $\mathrm{b}$.

2. SR merepresentasikan segitiga siku-siku untuk mengungkapkan informasi penting tentang masalah, namun kurang relevan dan kurang tepat, seperti yang disajikan gambar 15. SR merasa perlu merepresentasikan segitiga siku-siku, dikarenakan agar lebih mudah untuk menemukan cara dalam menjawab pertanyaan, sesuai petikan wawancara (PR203), (SR203), (PR204), (SR204). SR juga merasa yakin bahwa representasi segitiga siku-siku yang dibuat benar (SR217). Namun SR merepresentasikan informasi masalah tersebut kurang relevan dan kurang tepat, karena SR salah dalam merepresentasikan informasi panjang tali $50 \mathrm{~m}$ (PR218),(SR218)(PR219),(SR219), SR tidak membaca soal dengan cermat (SR220).

PR203: Apakah kamu perlu menggambarkan maksud soal tersebut?.

SR203: Perlu bu.

PR204: Kenapa perlu?.

SR204 : Karena untuk mempermudah saya menemukan cara/langkah-langkah penyelesaian.

PR217 : Apakah kamu yakin gambar yang kamu buat untuk menggambarkan maksud soal itu benar?

SR217: Iya bu, saya yakin.

PR218: Kenapa panjang tali 50 m nya kamu gambarkan pada sisi miring ini?.

SR218: Karena kan tali tiang bendera bu.

PR219: Coba baca soalnya kembali, terutama kalimat keduanya?.

SR219: (Subjek membaca soal kembali), oya bu, bukan tali tiang bendera.

PR220 : Kemudian, panjang tali yang dimaksud soal apa?.

SR220 : Jarak Rino terhadap tiang bendera, maaf bu saya tidak membaca soal dengan cermat.

3. SR mengidentifikasi konsep trigonometri dengan menggunakan aturan sinus, yang disajikan Gambar 17 dan petikan wawancara (PR215),(SR215).

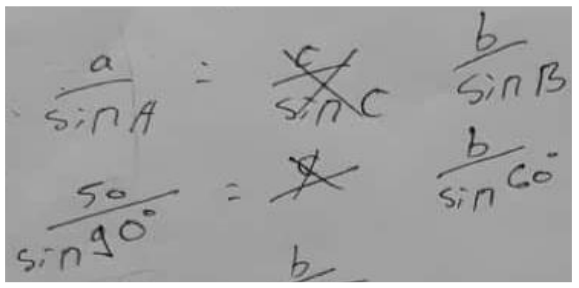

\section{Gambar 16. SR Mengidentifikasi Konsep Trigonometri}


PR215: Bagaimana langkah-langkah kamu selanjutnya dalam menyelesaikan soal ini?.

SR215 : Setelah menggambar maksud soal, saya mencari sudut C dari 180 dikurangi (90 tambah 60), kemudian saya mencari panjang b dengan rumus a per sin A sama dengan b per sin B, dengan a adalah panjang tali 50 m, sudut A 900 dan sudut B 600 . selanjutnya (SR membaca setiap langkah pekerjaan nya),ketemu panjang b sama dengan 25 akar 3 .

Selanjutnya, Setelah memahami masalah, SR membuat rencana penyelesaian masalah dengan melakukan aktivitas penalaran menggunakan koneksi yaitu SR mengoneksikan dengan materi perbandingan trigonometri (atuan sinus) dan sudut segitiga, sesuai petikan wawancara (PR212), (SR212). SR merasa tidak paham dengan nama dari materi-materi matematika (SR212),

PR212: Kira-kira rencana kamu akan menggunakan materi apa saja untuk menyelesaikan soal ini?.

SR212: (Sambil berfikir lama, karena siswa tidak paham nama materinya..tapi paham rumusnya) sinus bu, sudut segitiga.

Berdasarkan jawaban SR gambar 14. di atas, Setelah SR membuat rencana, SR melaksanakan rencana penyelesaian masalah dengan melakukan aktivitas penalaran menerapkan strategi penyelesaian masalah, yaitu:

1. SR menggunakan prosedur penyelesaian dengan mengatur langkah-langkah solusi yang terarah, namun beberapa perhitungan kurang tepat, seperti yang disajikan gambar 17. Langkah solusi SR yaitu menentukan sudut C (SR215); mencari panjang b (tinggi tiang bendera sampai batas mata Rino) dengan menggunakan rumus aturan sinus (SR215), kemudian mencari tinggi tiang bendera seluruhnya dengan menambahkan b dengan tinggi badan Rino dari mata hingga kaki (SR216). Adapun prosedur penyelesaian SR terarah namun kurang tepat dalam proses perhitungannya, diantaranya salah dalam merepresentasikan informasi soal pada gambar yang mengakibatkan salah dalam merumuskan aturan sinus yang digunakan. SR juga melakukan kesalahan dalam menjumlahkan bilangan bentuk akar, selain itu juga salah karena tidak memeriksa bilangan yang akan dijumlahkan satuannya sama atau berbeda, seperti yang disajikan gambar 17.
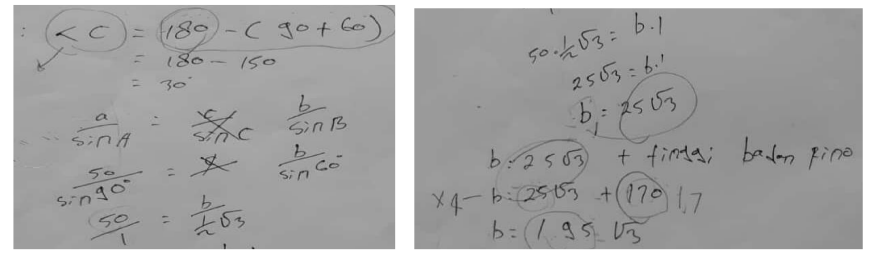

\section{Gambar 17. SR menggunakan prosedur penyelesaian terarah, namu perhitungannya kurang tepat}

PR215 : Bagaimana langkah-langkah kamu selanjutnya dalam menyelesaikan soal ini?.

SR215 : Setelah menggambar maksud soal, saya mencari sudut C dari 180 dikurangi (90 tambah 60), kemudian saya mencari panjang $b$ dengan rumus a per $\sin A$ sama dengan b per $\sin B$, dengan a adalah panjang tali $50 \mathrm{~m}$, sudut $A 90^{\circ}$ dan sudut $B$ $60^{\circ}$. selanjutnya (SR membaca setiap langkah pekerjaan nya), ketemu panjang b sama dengan 25 akar 3 .

PR216: Langkah selanjutnya?.

SR216 : Kemudian saya mencari tinggi tiang bendera dengan cara panjang b ditambah dengan tinggi badan Rino dari mata hingga kaki, 25 akar 3 ditambah 170 dan hasilnya 195 akar 3.

2. SR melakukan peninjauan strategi yang dipilih dengan melakukan pengecekan rumus (PR229), (SR229), dan SR melakukan coretan pada langkah solusinya dikarenakan rumus yang digunakan awalnya tidak sesuai (PR230), (SR230).

PR229: Apakah kamu mengecek kembali setiap langkah-langkah tersebut untuk memastikan arahan dalam menjawab solusi?.

SR229: Saya hanya mengecek rumus sinusnya bu, tidak mengecek perhitungannya bu, karena sudah pusing bu, soalnya sulit.

PR230 : Kok ada coretan di langkah mu ini?.

SR230 : oya bu, awalnya saya mau menggunakan rumus a per $\sin \mathrm{A}=\mathrm{c}$ per $\sin \mathrm{C}$, namun karena yang ditanyakan sisi $\mathrm{b}$, jai c per sin C saya ganti dengan b per sin B.

Berdasarkan jawaban SR gambar 14, setelah SR melaksanakan rencana, SR memeriksa kembali selesaian yang diperoleh dengan melakukan aktivitas penalaran merefleksikan solusi yaitu SR menafsirkan solusi untuk menjawab masalah dengan menyimpulkan bahwa tinggi tiang bendera tersebut adalah $195 \sqrt{3}$. seperti yang disajikan gambar 19 dan petikan wawancara (SR231). SR pun yakin dengan solusi yang diperolehnya (SR232), karena SR merasa perhitungan dan langkah pekerjaannya benar (SR233). 


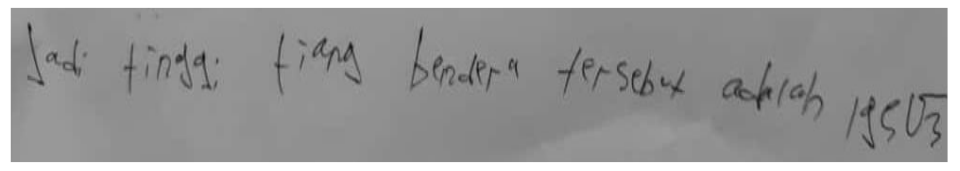

\section{Gambar 18. ST Menafsirkan Solusi}

PR231: Kesimpulanmu apa dalam menjawab soal ini?.

SR231 : Jadi tinggi tiang bendera tersebut adalah 195 akar 3.

PR232: Apakah kamu sudah yakin dengan jawabanmu?.

SR232: Yakin bu.

PR233 : Bagaimana cara kamu untuk menunjukkan jawabanmu itu benar?.

SR233 : Karena saya merasa perhitungan dan langkah langkah pekerjaan saya benar.

\section{PEMBAHASAN}

Dalam memahami masalah, ST melakukan aktivitas penalaran menganalisis masalah, yaitu: (1) ST, SS, SR mengungkapkan informasi penting tentang masalah dengan baik, yang ditunjukkan dengan menuliskan informasi yang ditanyakan dan menuliskan informasi yang diketahui dengan lengkap. Hal tersebut sesuai dengan pendapat (Shadiq, Mustajab, \& Amini, 2011) bahwa seseorang dinyatakan telah menguasai fakta jika ia dapat menuliskan fakta tersebut dan menggunakannya dengan benar. Lebih lanjut (Musser, Burger, \& Peterson, 2011) menyatakan bahwa siswa dapat memahami masalah dengan mengidentifikasi fakta atau informasi yang diberikan seperti apa yang diketahui dan ditanyakan dalam soal. (2) ST merepresentasikan segitiga siku-siku yang relevan dengan benar untuk mengungkapkan informasi penting tentang masalah, SS dan SR merepresentasikan segitiga siku-siku kurang relevan dan tidak benar. Hal ini dilakukan ST, SS dan SR agar lebih mudah untuk menemukan cara dalam menjawab pertanyaan, sesuai dengan (NTCM, 2000) bahwa representasi yang dimunculkan siswa merupakan ungkapan-ungkapan dari gagasan atau ide matematika yang ditampilkan siswa dalam upayanya mencari solusi dari masalah yang sedang dihadapinya. Lebih lanjut (Mustangin, 2015) mengatakan bahwa masalah dapat direpresentasikan dalam berbagai cara diantaranya dalam gambar, kata-kata (verbal), tabel, benda konkrit, atau simbol matematika. (3) ST mengidentifikasi konsep trigonometri yaitu perbandingan trigonometri tangen, sedangkan SS dan SR mengidentifikasi konsep trigonometri perbandingan trigonometri aturan sinus.

Dalam merencanakan masalah, ST, SS, dan SR melakukan aktivitas penalaran menggunakan koneksi, di antaranya ST mengoneksikan dengan materi perbandingan trigonometri pada segitiga siku-siku, SS dan SR mengoneksikan dengan materi perbandingan trigonometri aturan sinus. SS mengoneksikan dengan teorema Pythagoras. Hal tersebut sesuai dengan pendapat (Hodgson, 1995) yang menyatakan bahwa koneksi matematis merupakan alat pemecahan masalah. Jika siswa tidak mampu membangun suatu koneksi maka siswa tidak dapat memecahkan masalah.

Dalam melaksanakan rencana masalah, ST, SS, SR melakukan aktivitas penalaran menerapkan strategi, yaitu: (1) ST menggunakan prosedur penyelesaian secara terarah dengan mengatur langkah-langkah solusi dengan tepat. SS dan SR menggunakan prosedur penyelesaian dengan mengatur langkah-langkah solusi cukup terarah dan kurang tepat Sesuai dengan pendapat Sternberg (2003) menyatakan bahwa pada fase menyelesaikan yang merupakan ciri dari tahap menerapkan ide/strategi, siswa melakukan semua aktivitas matematika yang diperlukan untuk menyelesaikan masalah. Adapun prosedur penyelesaian SS cukup terarah namun beberapa perhitungan atau langkah solusi kurang tepat diantaranya salah dalam merepresentasikan maksud soal pada gambar yang mengakibatkan salah dalam merumuskan aturan sinus yang digunakan, salah dalam menentukan nilai trigonometri dari suatu sudut, salah dalam mengonversi satuan $\mathrm{cm}$ ke $\mathrm{m}$, salah dalam melakukan perhitungan pembagian dan atau merasioalkan bentuk akar, salah menggunakan konsep Pythagoras, salah dalam menjumlahkan bilangan bentuk akar. Begitu juga dengan SR, prosedur penyelesaian SR cukup terarah namun kurang tepat dalam proses perhitungannya, diantaranya salah dalam merepresentasikan maksud soal pada gambar yang mengakibatkan salah dalam merumuskan aturan sinus yang digunakan. SR juga melakukan kesalahan dalam menjumlahkan bilangan bentuk akar dan salah karena tidak memeriksa bilangan yang akan dijumlahkan mempunyai satuan yang sama atau berbeda. Hal tersebut sesuai dengan pendapat Polya (Musser \& Burger, 1991) menyatakan bahwa kesalahan pada langkah carry out the plan dapat berupa kesalahan pengunaan persamaan, rumus, atau kesalahan dalam perhitungan. Lebih lanjut, (Widodo, 2013) menjelaskan bahwa kesalahan siswa dalam menggunakan simbol berhubungan dengan kekurangcermatan siswa terkait dengan simbol-simbol matematika. (2) ST dan SS melakukan peninjauan strategi yang dipilih dengan pengecekan perhitungan/rumus.

Dalam memeriksa kembali, ST melakukan aktivitas penalaran merefleksikan solusi, yaitu: (1) ST menafsirkan solusi untuk menjawab secara implicit, tidak menuliskan kesimpulan terhadap solusi yang diperoleh, cukup dengan memberi dua garis bawah pada solusi yang diperoleh karena tidak terbiasa. SS pun tidak menuliskan kesimpulan solusi yang diperoleh, karena lupa dan tidak terbiasa. Sesuai dengan pendapat (Musdhalifah, 2013) menyatakan bahwa siswa yang memiliki kemampuan tinggi dan sedang sering untuk tidak menuliskan kesimpulan hasil jawaban. Berbeda dengan SR, SR menuliskan kesimpulan solusi yang diperoleh karena merasa yakin akan solusi tersebut. ST dan SR merasa yakin dengan jawaban yang ditemukan dan gambar yang dibuat karena merasa sudah melakukan perhitungan yang benar. (2) SS mempertimbangkan kewajaran solusi dengan 
mempertimbangkan hasil perhitungannya. Sehingga SS tidak yakin akan kebenaran jawabannya. Sesuai dengan pendapat yang dikemukakan oleh (Radatz, 1980) yaitu ketidakmampuan subjek menyelesaikan soal secara benar mengindikasikan bahwa subjek kurang memiliki keyakinan terhadap solusi yang diperoleh kurang berhati-hati dalam menyelesaikan soal, ataupun kondisi lainnya termasuk didalamnya kurangnya ketelitian subjek ketika menyelesaikan soal yang diberikan

\section{SIMPULAN}

Ketika memahami masalah, aktivitas penalaran menganalisis masalah: ST,SS dan SR mengungkapkan informasi penting tentang masalah dengan baik; ST dapat merepresentasikan segitiga siku-siku yang relevan, namun SS dan SR tidak relevan; ST mengidentifikasi konsep trigonometri tangen, sedangkan SS dan SR aturan sinus. Ketika merencanakan pemecahan masalah, aktivitas penalaran menggunakan koneksi, ST dapat mengoneksikan dengan materi perbandingan trigonometri tangen, SS dan SR materi perbandingan trigonometri aturan sinus. Ketika melaksanakan rencana masalah, aktivitas penalaran menerapkan strategi : ST menggunakan prosedur penyelesaian dengan mengatur langkah solusi secara terarah dan perhitungan tepat, namun SS dan SR perhitungan tidak tepat; ST dan SS melakukan peninjauan strategi yang dipilih dengan melakukan pengecekan perhitungan/rumus, namun SR tidak. Ketika memeriksa kembali, aktivitas penalaran merefleksikan solusi: ST dan SS tidak menuliskan kesimpulan solusi, namun dapat menafsirkan solusi secara lisan karena tidak terbiasa; ST dan SS dapat mempertimbangkan kewajaran solusi, namun SR tidak.

Kajian dalam penelitian ini masih terbatas pada kemampuan matematika, untuk memperkaya tinjauan pustaka, peneliti menyarankan dapat dilakukan penelitian lanjutan ditinjau dari aspek lainnya seperti gaya belajar, gaya kognitif, tingkat IQ dan gender. Selain itu, berdasarkan temuan penelitian siswa berkemampuan rendah dan sedang melakukan prosedur perhitungan matematika dan merepresentasikan informasi masalah yang tidak tepat sehingga guru dapat memilih strategi pembelajaran yang tepat untuk mengatasi temuan penelitian ini.

\section{DAFTAR RUJUKAN}

Durmus, S. (2004). Matematikte Öğrenme Güçlüklerinin Saptanmasi Üzerine bir Çalişma. Kastamonu Eğitim Dergisi, 125. Hodgson, T. R. (1995). Connections as Problem-Solving Tools. Connecting Mathematics across the Curriculum, 13-21. Krulik, S., Rudnick, J. A., \& Milou, E. (2003). Teaching Mathematics in Middle School: A Practical Guide. Allyn and Bacon. Lithner, J. (2008). A Research Framework for Creative and Imitative Reasoning. Educational Studies in Mathematics, 67(3), $255-276$.

Mueller, M., Yankelewitz, D., \& Maher, C. (2014). Teachers Promoting Student Mathematical Reasoning. Investigations in Mathematics Learning, 7(2), 1-20.

Musdhalifah, U. (2013). Analisis Kesalahan Siswa Kelas VII dalam Memecahkan Masalah Non Rutin yang Terkait dengan Bilangan Bulat Berdasarkan Tingkat Kemampuan Matematika di SMPN 31 Surabaya. MATHEdunesa, 2(3).

Musser, G., Burger, W., \& Peterson, B. (2011). Mathematics for Elementary Teacher a Contemporary Approach. Danvers, MA: PreMedia Global.

Musser, G. L., \& Burger, W. F. (1991). Mathematics for Elementary Teachers: A Contemporary Approach. MacMillan Publishing Company.

Mustangin, M. (2015). Representasi Konsep dan Peranannya dalam Pembelajaran Matematika di Sekolah. JPM: Jurnal Pendidikan Matematika, 1(1), 15-21.

NCTM. (2010). Why Is Teaching with Problem Solving Important to Student Learning?

Nurhajati, N. (2014). Pengaruh Penerapan Pendekatan Konstruktivisme dengan Model Pembelajaran Kooperatif Berbantuan Program Cabri 3D terhadap Kemampuan Penalaran dan Koneksi Matematis Siswa SMA di Kota Tasikmalaya. Jurnal Pendidikan dan Keguruan, 1(1).

Safrida, L. N., As'ari, A. R., \& Sisworo. (2016). Pengembangan Perangkat Pembelajaran Berbasis Problem Solving Polya untuk Meningkatkan Kemampuan Penalaran Matematis Siswa Materi Peluang Kelas XI SMA. Jurnal Pendidikan: Teori, Penelitian, dan Pengembangan, 1(4), 583-591.

Saglam, Z., Sevim, M., Yurtseven, T., Oguz, T., Yildirim, Y., \& Saglam, A. (2007). Matematik 10. Sinif Ders Kitabi. Istanbul: Rotamat Basim.

Shadiq, F., Mustajab, M., \& Amini, N. (2011). Penerapan Teori Belajar dalam Pembelajaran Matematika di SD. Yogyakarta. Suriasumantri, J. (2001). Filsafat Ilmu. Jakarta: Pustaka Sinar Harapan.

Tatar, E., Okur, M., \& Tuna, A. (2008). A Study to Determine Learning Difficulties in Secondary Mathematics Education. Kastamonu Education Journal, 16(2), 507-516.

Tuna, A. (2013). A Conceptual Analysis of the Knowledge of Prospective Mathematics Teachers about Degree and Radian. World Journal of Education, 3(4), 1-9.

Widodo, S. A. (2013). Analisis Kesalahan Dalam Pemecahan Masalah Divergensi Tipe Membuktikan pada Mahasiswa Matematika. Jurnal Pendidikan dan Pengajaran, 46(2). 